\title{
Extent of Knowledge and Level of Adoption of Hobbyists in Ornamental Fish Keeping and Aquarium Management in Tripura
}

\author{
Bonani Laskar ${ }^{1}$, Biswarup Saha ${ }^{2 *}$ and Atanu Sarkar ${ }^{1}$ \\ ${ }^{1}$ Dept. of Extension and Social Sciences, College of Fisheries, CAU (Imphal), Tripura (799 210), India \\ ${ }^{2}$ Dept. of Fishery Extension, Faculty of Fishery Sciences, WBUAFS, Chakgaria, Kolkata, W.B. (700 094), India
}

\section{Article History}

Manuscript No. AR1687

Received in $13^{\text {th }}$ September, 2016

Received in revised form $30^{\text {th }}$ November, 2016

Accepted in final form $6^{\text {th }}$ December, 2016

\section{Correspondence to}

"E-mail: biswarup.ext@gmail.com

\section{Keywords}

Aquarium fish keeping; hobbyists; knowledge; adoption; issues

\begin{abstract}
Aquarium fish keeping has been emerging as a popular hobby in Tripura. The study was conducted in the West Tripura district of Tripura in the year 2015-2016 among 100 randomly selected hobbyists of aquarium fish keeping. The data collected through observation and personal interview of the respondents revealed that majority of them were middle aged (36-50 years), all are literate and 50\% of them were graduates. Around $39 \%$ of the hobbyists were businessmen. Further, the majority of the respondents (38\%) were found to be spending ₹ 50-100 per month to manage their aquariums. Majority of the hobbyists (89\%) liked to keep Gold fish (Carassius auratus) in their aquarium followed by keeping shark (Carchardon carcharias) and Koi carp like Milky carp and Malina carp (Cyprinus carpio). Small to medium sized aquariums between $(2 \times 1 \times 1) \mathrm{ft}$ to $(3 \times 1 \times 1.5) \mathrm{ft}$ were having highest preference. Around $69 \%$ of the hobbyists were having medium level of adoption score in different improved practices of ornamental fish keeping and aquarium management and the adoption index of the study area was 68.09. The variables like knowledge, education, information management behaviour and income were having significant positive relationship with adoption level. On the other hand, $67 \%$ of the respondents had medium extent of knowledge score. Gross majority of them (80\%) flagged cleaning of tank to be their major issue whereas, $43 \%$ of them perceived that lack of scientific guidance regarding ornamental fish keeping and aquarium management was the major problem causing concern in continuing with the hobby.
\end{abstract}

\section{Introduction}

Ornamental fish keeping is emerging as one of the most popular hobbies across the world irrespective of age, class, creed or geographical variations in the residing area of hobbyists. Ornamental fishes market in the world for public aquaria is less than $1 \%$ at present and over $99 \%$ of the market for ornamental fish is still confined to hobbyist (Selvarasu and Sankaran, 2011). The attraction, relatively minimum requirement of space and attention compared to other pet animals is the reason for growing interest in keeping aquarium all over the world. In the contemporary times of space restrictions and craze for beautifying interiors, the aquariums have become an integral element of homes, offices, hospitals, hotels, business establishments, airports and other institutions. As popularity gained momentum, the need to transfer ornamental fishes from the resource abundant places to resource deficient places resulted in the marketing of ornamental fishes. The growing interest in aquarium fishes has resulted in steady increase in aquarium fish trade, globally. Ornamental fish is defined by
Dey (1996) as "attractive colorful fishes of peaceful nature that are kept in confined spaces of an aquarium or garden pool with the purpose of enjoying their beauty for fun \& fancy".

India is blessed with rich biodiversity of fresh water fishes both in North-Eastern Hills and Western Ghats. The Indian ornamental fish sector is a small but vibrant segment with potential for tremendous growth and large scale employment generation. At present the production of indigenous ornamental fishes from the country is mainly confined to freshwater varieties and based on wild collection. In fact $85 \%$ comes from North-Eastern states and Western Ghats. Indian water possess a rich biodiversity of about 2118 fish species, out of which more than 600 species exist in freshwaters. At present Indian domestic trade in ornamental fishes is estimated at only ₹ 10 crores. It is reported to be growing at a rate of $20 \%$ annually and the present demand is higher than the supply (Mandal et al., 2007).

Tripura contributes 123 fishes to the total 250 native ornamental fish species of north-eastern states (Mandal et al., 2007). Based 
on trade potentiality, the fish species belonging to the genera Notopterus, Amblypharyngodon, Danio, Devario, Esomus, Aorichthys, Parluciosoma, Rasbora reportedly found as high potential as ornamental fishes. However, they have not properly exploited in business point of view. Lack of scientific information on the native aquatic fauna, lack of business outlook may be the main reason for poor performance of this sector (Mandal et al., 2007). The ornamental fish industry has been identified as a powerful tool for rural income \& employment generation as it stimulates growth of a number of subsidiary industries besides being a foreign exchange earner.

In the present market scenario of ornamental fish industry, hobbyists have become very demanding. Firms face tough competition to retain the hobbyists because of their choice has been increasing rapidly. Constantly changing preferences and attitudes of hobbyists made the domestic ornamental fish market a dynamic one. In order to cater to this dynamic market, the entrepreneurs need to be very cautious regarding the knowledge, preference and adoption of improved production practices in ornamental fish rearing and management by the hobbyists. Consumer/hobbyists' understanding is the utmost important for the effective planning of their strategies to sustain business in the long run. Keeping all these in background, the study tries to analyze the hobbyists profile as well as their existing knowledge and level of adoption in different practices of ornamental fish keeping and issues perceived by them in aquarium management.

\section{Materials and Methods}

\subsection{Study sites}

The study was conducted during the year $2015-16$ by expostfacto research design. West Tripura district of Tripura was selected purposively for the present study because of the presence of diverse population interested in this hobby along with the number of aquarium shops are also largest among all the districts in the state so as trade volume. This district is also the major district of Tripura where the state capital is situated. Moreover, Mandal et al. (2007) reported that more than 2000 aquarium fish keepers are living in the Agartala city. Total 14 Traders actively involved in ornamental fish business in Agartala were identified by secondary sources as well as pilot study. The list of 600 hobbyists visiting the ornamental fisheries retail shops were prepared by the help of the identified traders and 100 hobbyists in ornamental fish keeping were selected accordingly by the help of simple random sampling method.

\subsection{Method of data collection}

A comprehensive list of items measuring knowledge and adoption of the hobbyists regarding ornamental fish keeping and aquarium management was prepared by consulting relevant literature as well as the experts of College of Fisheries, CAU(I), Tripura and ICAR NEH Regional Research Station, Tripura. Finally 30 items for measuring adoption and 40 items for measuring knowledge was selected through the judgment of a panel of 50 judges comprising teachers, researchers and extension personnel to rate each item on a five-point continuum from very important to less important. For the final selection of items, the item mean and standard deviation were taken into account. The hobbyists were personally interviewed using pre-tested designed interview schedule for capturing details on their socio-economic status and level of knowledge possessed and practices followed by them in ornamental fish keeping and aquarium management. Before going to final data collection, a pilot study was also carried out and accordingly appropriate changes in the construction and sequence of interview schedule were made. The schedule was administered to the respondents and the responses were recorded. The adoption and knowledge index was used to ascertain the adoption as well as knowledge level of all the recommended practices in this regards. A score 'one' was awarded for adopting the practice and 'zero' for non-adopting it. On the basis of overall adoption score, the respondents were classified as low, medium and high by using standard deviation and mean. The "adoption index" was calculated with the help of formula as given below:

Adoption index $=\frac{\text { Score obtained }}{\text { Maximum obtainable score }} \times 100$

The knowledge index was calculated with the following formula:

Knowledge index $=\frac{\mathrm{X} 1+\mathrm{X} 2+\mathrm{X} 3 \ldots . \mathrm{Xn}}{\mathrm{n}} \times 100$

Where, $\mathrm{X} 1, \mathrm{X} 2, \mathrm{X} 3$............................ $\mathrm{X} n=$ Scores of items and $n=$ No. of items.

On the basis of overall knowledge score, the respondents were classified as low, medium and high by using standard deviation and mean.

\section{Results and Discussion}

\subsection{Socio-economic profile of hobbyists}

Socio-economic profile of hobbyists was studied and findings are presented in Table 1. As per the table, it is found that $92 \%$ of hobbyists were men. Even $8 \%$ women were found as hobbyists in ornamental fish rearing in aquarium and with such acculturation of aquarium based ornamental fish keeping and in keeping parity with the observations of Felsing et al. (2000) in the matter of influence of cultural traditions and local customs in determining the extent of involvement of women, these cross section of women hobbyists even used to visit shops to buy fish or to maintain aquarium. Among the respondents while 44\% 


\begin{tabular}{|c|c|c|c|c|}
\hline $\begin{array}{l}\text { SI. } \\
\text { No. }\end{array}$ & $\begin{array}{l}\text { Name of the } \\
\text { variables }\end{array}$ & Category & $\begin{array}{l}\text { Fre- } \\
\text { quency }\end{array}$ & $\begin{array}{c}\text { Per- } \\
\text { centage } \\
(\%)\end{array}$ \\
\hline \multirow[t]{2}{*}{1.} & \multirow[t]{2}{*}{ Sex } & Male & 92 & 92 \\
\hline & & Female & 8 & 8 \\
\hline \multirow[t]{3}{*}{2.} & \multirow{3}{*}{$\begin{array}{l}\text { Age group } \\
\text { (years) }\end{array}$} & Young (18 to 35$)$ & 43 & 43 \\
\hline & & Middle (36 to 50 ) & 44 & 44 \\
\hline & & Old (50 and above) & 13 & 13 \\
\hline \multirow[t]{4}{*}{3.} & \multirow{4}{*}{$\begin{array}{l}\text { Educational } \\
\text { level }\end{array}$} & Up to middle school & 3 & 3 \\
\hline & & Up to high school & 35 & 35 \\
\hline & & Graduate & 50 & 50 \\
\hline & & Post graduate & 12 & 12 \\
\hline \multirow[t]{7}{*}{4.} & \multirow[t]{7}{*}{ Occupation } & Student & 1 & 1 \\
\hline & & Pvt. employee & 18 & 18 \\
\hline & & Govt. servant & 30 & 30 \\
\hline & & Unemployed & 1 & 1 \\
\hline & & Own business & 39 & 39 \\
\hline & & Retired person & 9 & 9 \\
\hline & & Farmers & 2 & 2 \\
\hline \multirow[t]{7}{*}{5.} & \multirow{7}{*}{$\begin{array}{l}\text { Total annual } \\
\text { income }(₹)\end{array}$} & Up to 72,000 & 2 & 2 \\
\hline & & $72,001-1,44,000$ & 15 & 15 \\
\hline & & $1,44,001-2,16,000$ & 27 & 27 \\
\hline & & $2,16,001-2,88,000$ & 28 & 28 \\
\hline & & $2,88,001-3,60,000$ & 10 & 10 \\
\hline & & $3,60,001-4,32,000$ & 5 & 5 \\
\hline & & $4,32,001$ and above & 13 & 13 \\
\hline \multirow[t]{5}{*}{6.} & \multirow{5}{*}{$\begin{array}{l}\text { Monthly } \\
\text { expenditure } \\
\text { in aquarium } \\
\text { manage- } \\
\text { ment }(₹)\end{array}$} & Upto 50 & 21 & 21 \\
\hline & & $51-100$ & 38 & 38 \\
\hline & & $101-150$ & 19 & 19 \\
\hline & & $151-200$ & 9 & 9 \\
\hline & & 200 and above & 13 & 13 \\
\hline \multirow[t]{4}{*}{7.} & \multirow{4}{*}{$\begin{array}{l}\text { Experience } \\
\text { (Years) }\end{array}$} & Less than 5 years & 51 & 51 \\
\hline & & $\begin{array}{c}\text { More than } 5 \text { years - } \\
10 \text { years }\end{array}$ & 38 & 38 \\
\hline & & $\begin{array}{l}\text { More than } 10 \text { years } \\
-20 \text { years }\end{array}$ & 9 & 9 \\
\hline & & More than 20 years & 2 & 2 \\
\hline
\end{tabular}

were middle aged ( 36 to 50 years old), $43 \%$ were from younger age (18 to 35 years old) category. All the hobbyists were noted to be educated and majority (50\%) of them was graduate degree holders. Most of the respondents were businessmen (39\%) followed by Govt. Servant (30\%). $18 \%$ of them were employed in private sector while $9 \%$ were retired persons. Two per cent of the hobbyists were farmers and $1 \%$ was student. In terms of experience in keeping ornamental fishes, while only $2 \%$ of the respondents were found to be remaining involved in this hobby for more than 20 years, $38 \%$ of them were found to be associated in it during 5-10 years and 9\% during 10-20 years. Majority of the respondents (51\%) became involved in this hobby within five years. It is also reveling from the Table 1 that monthly expenditure in managing aquarium for $38 \%$ of the respondents was to the tune of ₹ 51-100. And those were between ₹ 101-200 and above ₹ 200 for $28 \%$ and $13 \%$ of the respondents respectively. In accordance with annual income of the hobbyists, while $28 \%$ of the respondents who were rearing ornamental fishes had their income ranging between Rs. $2,16,001-2,88,000$ per annum, for $27 \%$ cases it was in the rage of ₹ 1,44,001-2,16,000 annum ${ }^{-1}$.

\subsection{Aquarium keeping pattern and related issues}

Majority of the hobbyists (89\%) liked to keep Gold fish (Carassius auratus) in their aquarium followed by keeping shark (Carchardon carcharias) and Koi carp like Milky carp and Malina carp (Cyprinus carpio). Majority of the hobbyists $(79 \%)$ were preferred to keep combination of two species in their aquarium. Most of the them (25\%) enjoyed the combination of Gold fish (Carassius auratus) and Shark (Carchardon carcharias) in their aquarium followed by $20 \%$ of the hobbyists liked to keep Gold fish (Carassius auratus) and Red cap in their aquarium. While $99 \%$ of the respondent households were found to be keeping one aquarium, only a meager $1 \%$ of them were found to have two aquariums in their home (Table 2). Further, supplementary information collected in this regard was reflective of the fact that none of the respondents increased their number of aquarium since they started keeping aquarium as hobby. In terms of nativity of the aquarium owners under study, Table 2 is reveling of the fact that as high as $91 \%$ of them were residents of municipal areas. And those were followed in descending order by the residents of corporation (6\%) and panchayat (3\%) areas.

In terms of aquarium size as being maintained by the respondents, wide variations could be noted. A glance at Table 3 shows that altogether seven sizes of aquarium are getting maintained by the respondent households of which the medium sized aquariums having $(3 \times 1 \times 1) \mathrm{ft}$ dimension were under widest use $(25 \%)$ as followed closely by smallest

\begin{tabular}{|c|c|c|c|c|}
\hline \multirow{2}{*}{$\begin{array}{l}\text { No. of } \\
\text { aquarium } \\
\text { in posses- } \\
\text { sion }\end{array}$} & \multicolumn{3}{|c|}{$\begin{array}{l}\text { Percentage distribution accord- } \\
\text { ing to location of residence }\end{array}$} & \multirow[t]{2}{*}{$\begin{array}{l}\text { Cumulative } \\
\text { percentage }\end{array}$} \\
\hline & $\begin{array}{l}\text { Corpora- } \\
\text { tion }\end{array}$ & $\begin{array}{l}\text { Munici- } \\
\text { pality }\end{array}$ & $\begin{array}{l}\text { Pan- } \\
\text { chayat }\end{array}$ & \\
\hline 1 & 6 & 90 & 3 & 99 \\
\hline 2 & 0 & 1 & 0 & 1 \\
\hline Total & 6 & 91 & 3 & 100 \\
\hline
\end{tabular}


sized $(2 \times 1 \times 1) \mathrm{ft}$ ones $(23 \%)$. It was also observed from Table 3 that aquariums having larger sizes with their corresponding dimensions being $(4 \times 1 \times 1) \mathrm{ft},(4 \times 1 \times 1.5) \mathrm{ft},(5 \times 1 \times 1) \mathrm{ft}$ were under possession by $12 \%, 6 \%$ and $5 \%$ respectively. Moreover, $13 \%$ of the respondents were detected to be having smaller sized $(2 \times 1 \times 1.5) \mathrm{ft}$ aquariums under their possession. Thus, small to medium sized aquariums with the dimensions ranging between $(2 \times 1 \times 1) \mathrm{ft}$ to $(3 \times 1 \times 1.5) \mathrm{ft}$ were having highest preference $(71 \%)$ by the investigated aquarium owners. The

Table 3: Distribution of hobbyists according to size of the aquarium in household

\begin{tabular}{lccccc}
\hline $\begin{array}{l}\text { SI. } \\
\text { No. }\end{array}$ & $\begin{array}{c}\text { Size of } \\
\text { aquarium } \\
\text { (feet) }\end{array}$ & $\begin{array}{c}\text { Cat- } \\
\text { egory }\end{array}$ & $\begin{array}{c}\text { Fre- } \\
\text { quency } \\
(\mathrm{f})\end{array}$ & $\begin{array}{c}\text { Size } \\
\text { wise } \\
(\%)\end{array}$ & $\begin{array}{c}\text { Category } \\
\text { wise } \\
(\%)\end{array}$ \\
\hline 1. & $2 \times 1 \times 1$ & & 23 & 23 & 36 \\
2. & $2 \times 1 \times 1.5$ & Small & 13 & 13 & \\
3. & $3 \times 1 \times 1$ & Me- & 25 & 25 & 41 \\
4. & $3 \times 1 \times 1.5$ & dium & 16 & 16 & \\
5. & $4 \times 1 \times 1$ & Large & 12 & 12 & 23 \\
6. & $4 \times 1 \times 1.5$ & & 6 & 6 & \\
7. & $5 \times 1 \times 1$ & & 5 & 5 &
\end{tabular}

supporting information contextual to the possible rationale behind using such variable sizes of aquarium was mentioned to be space compatibility, relative ease in maintenance and cost affordability from the part of the aquarium owners under investigation to be the prime reasons behind opting for small to medium sized aquariums while fulfilling their hobby.

In view of getting a clearer picture behind liking ornamental fish keeping, hobbyists' perceived reasons to that effect was also studied. In accordance with the Figure 1, while $81 \%$ of sample households were expressive of their inquisitiveness in watching fishes swimming and playing inside aquariums, $10 \%$ indicated that they became inclined to this hobby for reducing their tension in daily life. Still further, while $7 \%$ of the respondents were communicative that this hobby could help them in spending good time, the remaining $2 \%$ viewed that the hobby had been revealing of their economic status.

Figure 2 revealed that majority of the hobbyists (51\%) were of the habit of purchasing fishes once in 4-6 months and $40 \%$ of them were tending to purchase once in 2-4 months. Further, among the respondents, $5 \%$ were found to have the habit of purchasing fishes once in a month and only $1 \%$ of them were observed to be purchasing ornamental fishes on fortnightly basis. Moreover, $3 \%$ of the respondents indicated that they purchase fishes on as and when required basis.

\subsection{The level of adoption and the extent knowledge of hobbyists}

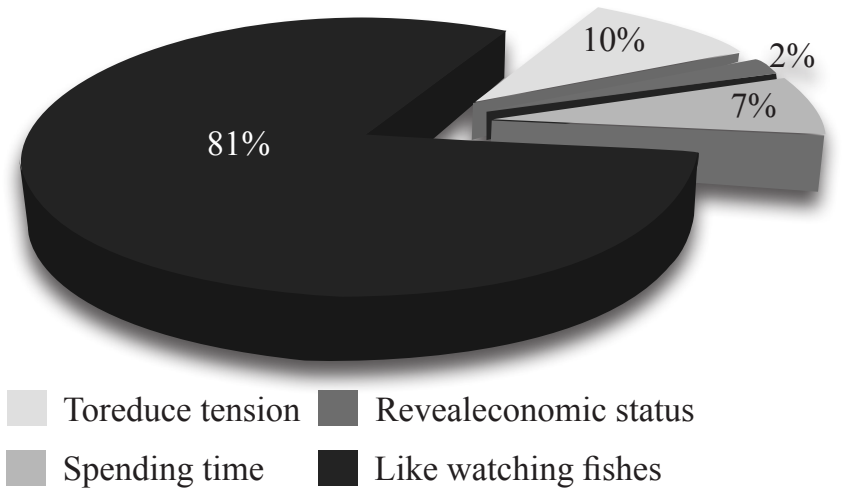

Figure 1: Hobbyists' perceive reasons for starting ornamental fish keeping in their household

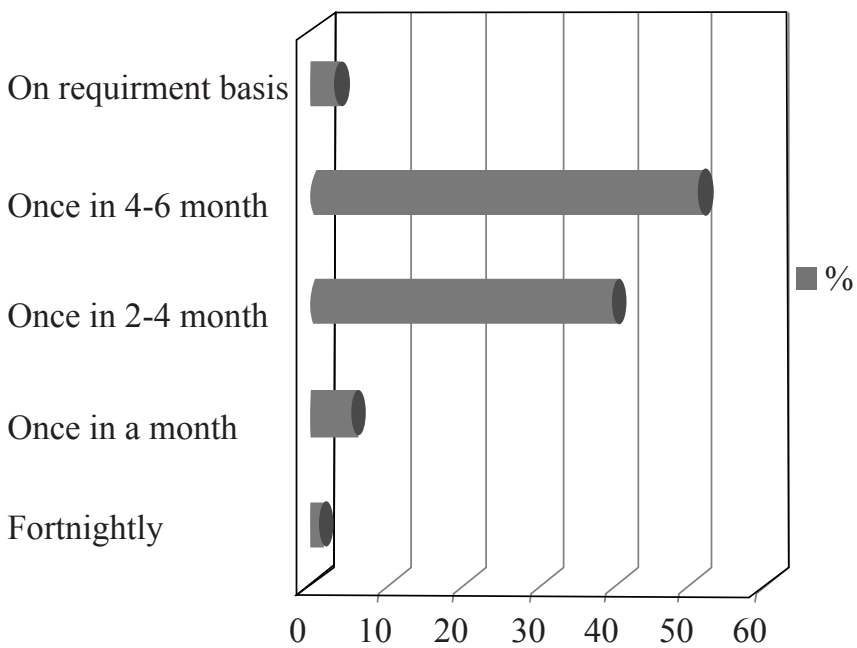

Figure 2: Distribution of hobbyists according to frequency of buying fish

in ornamental fish keeping and aquarium management

The distributive pattern of the hobbyists on the basis of their level of adoption of ornamental fish keeping and aquarium management practices has been presented through Figure 3. It was transpired from the figure that majority $(69 \%)$ of the respondents were having medium level of adoption score as against $18 \%$ occupying high level of adoption score and 13\% occupying low level of adoption score. The adoption index of the study area was 68.09. The study revealed that majority of the hobbyists were found to feed their ornamental fishes once a day instead of giving twice a day and a very few of them found to be used immustimulant/probiotics for their reared ornamental fish which can be kept them healthy. The reason behind may be due to lack of awareness regarding ornamental fish keeping and aquarium management among hobbyists.

In order to find out the relationship between the identified explaining profile of respondents and level of adoption, correlation coefficients were worked out and the results have been getting presented through Table 4 . It is indicative from 


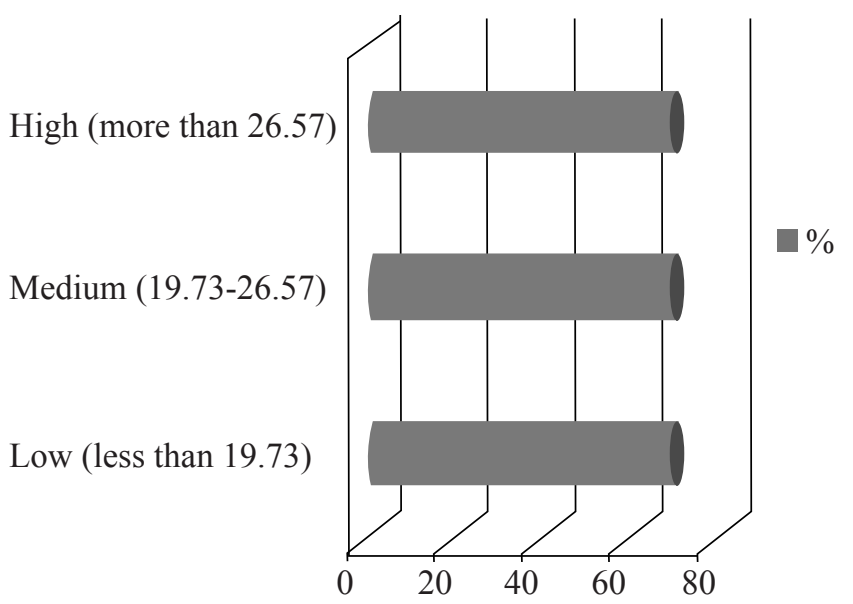

Figure 3: Distribution of hobbyists as per their level of adoption on ornamental fish keeping and aquarium management

the table that while knowledge, education and income were having significant positive relationship with level of adoption at $1 \%$ level of significance, information management behaviour was found to have positive relation with adoption level of ornamental fish keeping and aquarium management at 5\% level of significance.

Distribution of hobbyists as per their knowledge score on ornamental fish keeping and aquarium management has been depicted in Figure 4. It is clearly visible from figure that $67 \%$ of the respondents had medium extent of knowledge regarding different practices of ornamental fish keeping and aquarium management. Around 20\% respondents had low level of adoption score followed by $13 \%$ respondents had high level of knowledge score. Knowledge index of the study area was

Table 4: Correlation of independent variables with level of adoption

\begin{tabular}{llc}
\hline $\begin{array}{l}\text { Sl. } \\
\text { No. }\end{array}$ & Variable & $\begin{array}{c}\text { Correlation } \\
\text { coefficient }(\mathrm{r})\end{array}$ \\
\hline 1. & Knowledge & $0.798^{* *}$ \\
2. & Area & 0.107 \\
3. & Sex & -0.125 \\
4. & Age & 0.155 \\
5. & Education & $0.276^{* *}$ \\
6. & Occupation & 0.092 \\
7. & Income & $0.307^{* *}$ \\
8. & Experience & 0.12 \\
9. & Frequency of fish purchases & 0.141 \\
10. & Expenditure on fish purchases & 0.033 \\
11. & Tank size & 0.139 \\
12. & Information management behaviour & $0.209^{*}$ \\
\hline
\end{tabular}

*: indicates significance at $(p=0.05)$ level of significance;

$* *$ indicates $(p=0.01)$ level of significance
55.56. Further, it was observed that none of the hobbyists knew about the live food organisms which are a very good source of nutrient of ornamental fishes. Majority of them did not know about proper treatment of any disease regarding ornamental fishes.

In order to find out the relationship between the identified explaining profile of respondents and extent of knowledge, correlation coefficients were worked out and the results have been getting presented through Table 5. It is indicative from the table that while experience was having significant positive relationship with extent of knowledge at $1 \%$ level of significance, information management behaviour was found to have positive relation with knowledge level of ornamental fish keeping and aquarium management at $5 \%$ level of significance.

High (more than 27.4)

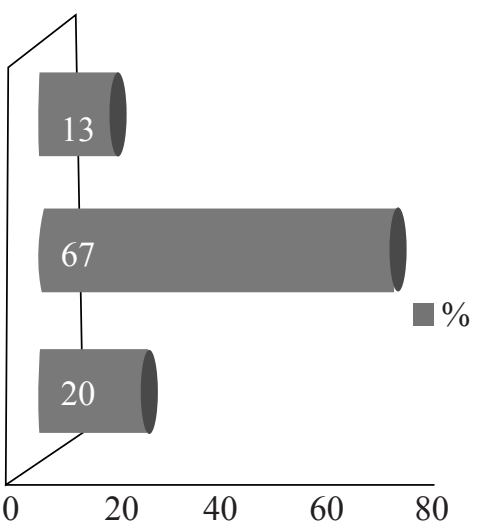

Figure 4: Distribution of hobbyists as per their extent of knowledge on ornamental fish keeping and aquarium management

Table 5: Correlation of independent variables with extent of knowledge

\begin{tabular}{llc}
\hline $\begin{array}{l}\text { Sl. } \\
\text { No. }\end{array}$ & Variable & $\begin{array}{c}\text { Correlation } \\
\text { coefficient }(\mathrm{r})\end{array}$ \\
\hline 1. & Area & 0.149 \\
2. & Sex & -0.038 \\
3. & Age & 0.78 \\
4. & Education & 0.171 \\
5. & Occupation & 0.038 \\
6. & Income & -0.27 \\
7. & Experience & $0.305^{* *}$ \\
8. & Frequency & -0.137 \\
9. & Expenditure & 0.084 \\
10. & Tank size & 0.073 \\
11. & Information managemnet behaviour & $0.201^{*}$ \\
\hline
\end{tabular}

*: indicates significance at $(p=0.05)$ level of significance;

**: indicates $(p=0.01)$ level of significance 
3.4. Major issues and problems perceived by the hobbyists in aquarium management

Figure 5: provides perceived major issues on the part of aquarium hobbyists. As perceived by the aquarium keepers, while a gross majority of them ( $80 \%$ ) flagged cleaning of tank to be their major issue causing concern in continuing with the hobby, in order of descend the other identified issues were diseases $(11 \%)$ and regularity in feeding (7\%). None of the aquarium hobbyists was expressive of any prevailing climatic parameter in the state that was causing concern to them.

Categorization of hobbyists as per problems that they faced while buying fishes are depicted in the Figure 6. It was found that majority of the consumers ( $43 \%$ ) revealed that traders are failed to provide scientific guidance regarding ornamental fish keeping and aquarium management out of which 32 belonged to municipality area and $35 \%$ consumers found price was differ from shop to shop. $13 \%$ consumers claimed that required species were not available in shop.

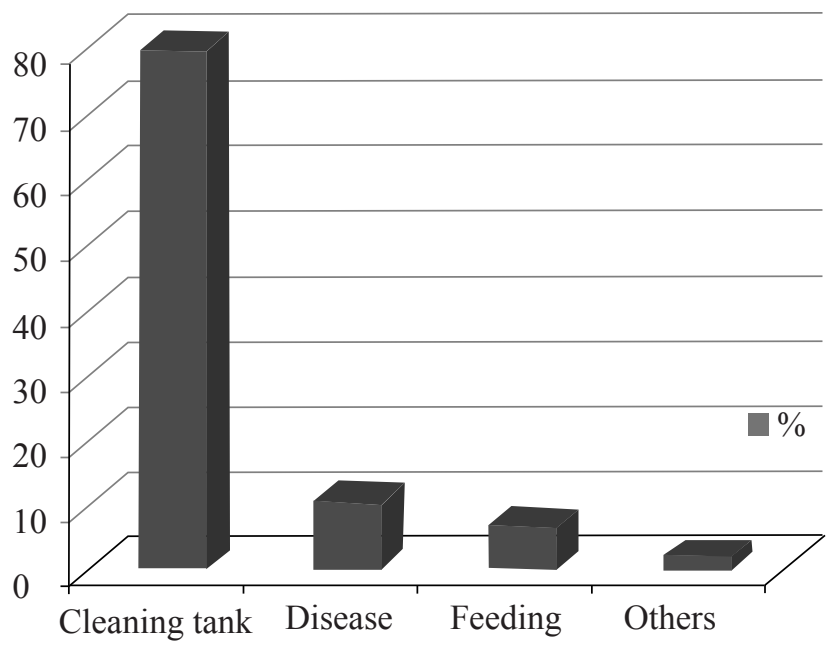

Figure 5: Major issues in keeping aquarium at home perceived by the hobbyists

\section{Conclusion}

Ornamental fish industry is having huge potentiality and as an emerging field of business. Majority of the hobbyists were having medium level of knowledge and moderate rate of adoption regarding different practices of ornamental fish keeping and aquarium management. Respondents were found mostly unacquainted about the different requirements of aquarium fish keeping and management. They consult shopkeepers every time when a problem arises in feeding, disease and exchange of water. However, effective mechanism for need based training programme of traders vis-a-vis hobbyists is very important to support the ornamental fish industries. As education, income knowledge and information management behavior were having significant positive relationship with level of adoption.

\section{Acknowledgement}

The authors express their sense of gratitude to the Dean and other faculty members of College of Fisheries, CAU (I), Lembucherra, Tripura. The authors are also grateful to the respondents of the study.

\section{References}

Dey, V.K., 1996. Ornamental Fishes: Handbook of Aquafarming. The Marine Products Export Development Authority, Kochi, 76.

Felsing, M., Brugere, C., Kusakabe, K., Kelkar, G., 2000. Women for aquaculture or aquaculture for women?, Infofish International, 3/2000: 34 behaviour -40 .

Mandal, S., Mahapatra, B.K., Tripathi, A.K., Verma, M.R., Datta, K.K., Ngachan, S.V., 2007. Agribusiness opportunity of ornamental fisheries in north-eastern region of India. Agricultural Economics Research Review, 20, 471-488.

Selvarasu, A., Sankaran, A., 2011. Marketing Strategies vis- $a$ vis Consumer Preference for Aquarium Business Service, International Journal of Latest Trends in Finance and Economic Sciences 1(1), 23-29. 